\title{
Use of Kahoot media and variations of questions on learning achievement with motivation as moderation
}

\author{
Bila Anggraini ${ }^{*}$ \\ Nurdin ${ }^{2}$ \\ Pujiati $^{3}$ \\ ${ }^{1-3}$ Faculty of Teacher Training and Education, Universitas Lampung, Bandar Lampung City, Indonesia
}

\begin{abstract}
This study aims to determine whether there is an influence of the use of Kahoot and the variation of questions on learning achievement with motivation as a moderator. The populations were the tenth-grade students of social sciences at SMA Negeri 1 Sumberejo in the 2019/2020 academic year, with a sample of 81 students determined using a Cochran formula. The study adopted a descriptive verification method with ex-post facto and survey approaches. The collected data were analysed using a linear regression test with path analysis. The results indicate that there is an influence of the use of Kahoot media, the variation of questions, and learning motivation on the economic learning achievement among the tenthgrade students of social sciences at SMA Negeri 1 Sumberejo in the academic year of 2019/2020.
\end{abstract}

\section{KEYWORDS}

Economics learning achievement; Kahoot media; motivation; variation of questions

Received: 31 January 2021

Accepted: 2 February 2021

Published: 4 February 2021

\section{Introduction}

Indonesia is currently faced with an era of industrial revolution 4.0. The changes that have occurred in this era demand Indonesia to quickly and dynamically innovate. To adjust and be able to compete on a global scale in the era of industrial revolution 4.0, the country needs to prepare adequate and character human resources (HR). In line with this, education sector is the main key in shaping students' character and abilities, both from their attitudes and actions to be more critical in understanding something. Education can also be used to measure the abilities and talents of students that must be developed so that students have a better scientific field, can practice and apply their knowledge as provisions in the future (Idris, Hassan, Ya'acob, Gill, \& Awal, 2012).

The purpose of education is to form a complete human being, to be devoted to God the Almighty, to know, have a noble character, and be responsible for the nation. Education also aims to develop the potential of students to achieve the desired goals. Education can serve as motivation for students to compete to be better in all aspects of life.

Learning motivation can be increased by way of utilizing instructional media. Learning media in the teaching and learning process can generate new desires and interests, generate motivation and stimulation of learning activities and bring psychological influences on students 
(Azhar, 2007). With the rapid development of science and technology, this can be used by educators and students in learning, one of which is by using Information and Communication Technology (ICT)-based applications or online (Youssef \& Dahmani, 2008). The entry of the digital era that involves all life processes can increase students' interest in the teaching and learning process and impact increasing student learning achievement. Fun learning becomes a benchmark that keeps students motivated to improve their knowledge and skills in lessons. According to Bennett (2007), multimedia-based learning in the form of audio and visuals stimulates students' five senses; the learning media must also be interactive, which promotes cooperation, communication, and interaction between students so that learning can be more powerful and can improve student learning achievement. According to Wasliman (as cited in Susanto, 2013), students' learning achievement can be influenced by several factors, including intrinsic factors (from within students) and extrinsic factors (from outside students). A factor that comes from within students is, for example, is learning motivation and factors that come from outside of students are, for example, curriculum, teachers, learning media, and facilities. In addition to these factors, the variation of questions or tests and the quality of the questions made by educators to measure students' cognitive learning achievement also play an important role. Varied and quality educators' questions make students work on questions enthusiastically. The varied and quality questions mean that the questions not only measure the ability to remember $(\mathrm{C} 1)$, but also to measure the ability to understand (C2), apply (C3), analyze (C4), evaluate/assess (C5), and create (C6) (Krathwohl, 2002). Therefore, to achieve a good learning, achievement must be supported by good components as well.

However, based on the results of observations in one of schools that has implemented online exams for three years, especially in economic subjects, namely SMA Negeri 1 Sumberejo, Lampung Province, it was found that the learning achievement of students in economic subjects was still low. The learning achievement could be seen from daily tests scores of economic subject of the tenth grade students of social science class in the odd semester of 2019/2020 academic year with a minimum completion criterion (KKM) score of 76. Of the total 102 students, 40 students scored $\geq 76$, while 62 of the 102 participants students have not reached the KKM $(<76)$. It was identified that the questions made by educators were not varied and limited only to the ability to remember (C1), understand (C2), and apply (C3). Besides, based on our observation, it was found that instructional media, especially those based online, in the implementation of teaching and learning were not well implemented. They only used printed books provided by the government so that students seemed less enthusiastic during learning. As a result, each student's learning motivation was different even though, when viewed from the availability of learning facilities, SMA Negeri 1 Sumberejo had already had the Internet access and LCD facilities. Moreover, most educators and students also had their own laptops and smartphones that they could use in the learning process. Considering that learning media is one of the factors that affects students' motivation and learning achievement, we conducted preliminary research to determine the needs of students for online learning, especially using Kahoot media. The questionnaire distributed to 102 students showed that a total of 74 participants stated that they strongly agreed and agreed to use Kahoot media in teaching and learning process.

Kahoot is a learning media based on online educational games in which there are several icons to develop (Dewi, 2018). One of the icons is the quiz icon, where students can participate in responding to quizzes, discussions, and surveys. Students who participate in this game do not need to create a new account because it can be accessed directly through a web browser available on gadgets, laptops, or computers. Quizzes, discussion forums, or survey forums can be created after the teacher creates a new account on the Kahoot page. Quizzes are not only in written questions, but pictures, videos, and songs can be inserted to support their thinking power in understanding quizzes (Dellos, 2015). Kahoot is attractive and colorful in appearance, encouraging active participation of students, free access with various forms of questions, easy to use, allowing shy students to answer questions without shame, can accommodate students with color vision disorders (Boden \& Hart, 2018). Confirming Boden \& Hart's statement, several researchers have conducted research that shows that online learning media, namely Kahoot, can increase students' motivation and learning achievement (Setiawati, Sihkabuden, \& Adi, 2019). 
Based on the background of the problems described above, if the motivation to learn economics is low, the application of learning media, and the variation of questions is not optimal, the learning achievement will also be low. However, this statement still needs scientific proof. Therefore, we were interested in investigating the effect of Kahoot and problem variations on learning achievement in Economics subject with motivation as moderation.

\section{Literature review}

According to Dewi (2018), Kahoot is an education-based game in which there are several icons to develop. One of them is the quiz icon where users can make applications using Kahoot for learning to be interesting and not boring. The use of Kahoot media is an intermediary or online media to convey information for students to learn. With the media, it is hoped that the learning process will be easier for students. In this study, it was measured by skills using online-based Kahoot media, Kahoot media functions, benefits of Kahoot, and Kahoot steps. To support the use of the media, the quiz on Kahoot was made with a variety of questions. Question variations are all forms of questions seen from the level of thinking of students starting from remembering (C1), understanding (C2), applying (C3), analyzing (C4), observing/assessing (C5), and creating (C6) (Krathwohl, 2002). The use of media and a variety of questions to increase student motivation in learning and help improve student achievement. Fun learning becomes a benchmark that keeps students motivated to improve their knowledge and skills in a lesson. According to Tu'u (2004), learning achievement is the mastery of knowledge or skills developed by subjects, usually indicated by test scores or numbers given by a teacher. Meanwhile, learning motivation is fighting internally and externally on students who are learning to make a behavior change, generally with several indicators or elements that support (Uno, 2008). In this regard, Wasliman (as cited in Susanto, 2013), student achievement can be identified by several factors, including intrinsic factors (from within students) and extrinsic factors (from outside students). One of the factors that comes from within the student is learning motivation and factors that come from outside the student include curriculum, teachers, learning media, and facilities. Apart from these factors, the variation of questions or tests and the quality of the questions made by educators to measure students' cognitive learning achievement are also important. Educator's varied and quality questions make students well prepared to respond to questions.

\section{Methods}

This study adopted a descriptive verification method using ex-post facto approaches and surveys. Specifically, this study only describes the effect of using Kahoot media and the variation of questions on economic learning achievement with motivation as moderator.

\section{Participants}

A total of 102 students who were in the tenth grade of SMA Negeri 1 Sumberrejo took part in the current study. They were divided into three classes, namely X IPS 1, X IPS 2, and X IPS 3 with a total of 34 students in each class respectively.

\section{Instruments}

This study employed several instruments for data collection including observation, documentation, economic learning achievement tests, and questionnaires.

Observation was used to systematically obtain, analyze, and record behaviors systematically by observing students in each class related to their learning achievement in economics subject and several factors that were thought to influence it

Documentation was used to obtain data in the form of notes. This technique was used to collect data about student grades, school profiles, facilities and infrastructure, and students' number to be studied. 
Tests were used to measure students' abilities in the form of economics learning achievement. The tests used were in the form of knowledge tests on economics subjects in the form of multiple choice-tests. A written test was also used to determine the variation of questions, and economics learning achievement carried out at the final stage of the learning process.

Questionnaire was used to obtain information about Kahoot media's influence and the motivation to learn economics subject.

\section{Data analysis}

The collected data in this study were analyzed using a linear regression test with path analysis (Path Analysis).

\section{Results}

\section{The effect of using Kahoot media on learning motivation}

The hypothesis testing was carried out using SPSS, the following results were obtained.

Table 1. Hypothesis testing the effect of using Kahoot media on learning motivation

\begin{tabular}{cccc}
\hline Variable & $\mathrm{t}_{\text {count }}$ & $\mathrm{t}_{\text {table }}$ & Sig. \\
\hline Use of Kahoot media & 4,786 & 1,99045 & 0,000 \\
\hline
\end{tabular}

The results of the above calculations show that the $t_{\text {count }}$ is 4.786 and the significance level (sig.) is 0.000 . While $\mathrm{t}_{\text {table }}$ with $\mathrm{dk}=\mathrm{n}-2=81-2=79$ and $\alpha=0.05$ obtained 1.99045 (result of interpolation); thus, $\mathrm{t}_{\text {count }}>\mathrm{t}_{\text {table }}$ or 4.786 $>1.990$ and Sig. $0.000<0.05$, then $\mathrm{H}_{0}$ is rejected, and $\mathrm{H}_{1}$ is accepted, which means that Kahoot media use has a significant effect on learning motivation for the tenth-grade students of social sciences at SMA Negeri 1 Sumberejo in the 2019/2020 academic year.

\section{The effect of question variations on learning motivation}

The hypothesis testing of the effect of question variations on learning motivation was carried out with the help of SPSS, and the following results were obtained.

Table 2. Hypothesis test results the effect of question variations on learning motivation

\begin{tabular}{cccc}
\hline Variable & $\mathbf{t}_{\text {count }}$ & $\mathbf{t}_{\text {table }}$ & Sig. \\
\hline Variation of questions & 4,043 & 1,99045 & 0,000 \\
\hline
\end{tabular}

The results of the above calculations in Table 2 show that the $t_{\text {count }}$ is 4.043 , and the significance level (sig.) is 0.000 . While $\mathrm{t}_{\text {table }}$ with $\mathrm{dk}=\mathrm{n}-2=81-2=79$ and $\alpha=0.05$ obtained 1.99045 (result of interpolation); thus $\mathrm{t}_{\text {count }}>\mathrm{t}$ table or $4.043>1.990$ and Sig. $0.000<0.05$, then $\mathrm{H}_{0}$ is rejected, and $\mathrm{H}_{1}$ is accepted, which means that the use of question variations has a significant effect on learning motivation for the tenth-grade students of social sciences at SMA Negeri 1 Sumberejo in the 2019/2020 academic year.

\section{The relationship between using Kahoot media and problem variations}

The hypothesis testing of the relationship between the use of Kahoot media and variations of questions was carried out with the help of SPSS, the following results were obtained. 
Table 3. Hypothesis test results using Kahoot media with variation of questions

\begin{tabular}{ccc}
\hline Variable & Pearson Correlation & Sig. \\
\hline Use of Kahoot media & 0,964 & 0,000 \\
Variations of questions & 0,964 & 0,000 \\
\hline
\end{tabular}

Based on the analysis in Table 3 above, the correlation figure between the use of Kahoot media and question variations is 0.964 . Whereas $\mathrm{r}_{\text {table }}$ with $\mathrm{dk}=81$ and $\alpha=0,05$ obtained 0.1818 , thus $r_{\text {count }}>r_{\text {table }}$ or $0.964>0.182$ then $\mathrm{H}_{0}$ is rejected, and $\mathrm{H}_{1}$ is accepted. In other words, there is a relationship between the use of Kahoot media and the variation of questions of the tenth-grade students of social sciences at SMA Negeri 1 Sumberejo in the Academic Year of 2019/2020. The correlation coefficient of 0.964 means that the relationship between the variable use of Kahoot media and the variation of questions is strong and unidirectional (because the results are positive).

\section{The effect of using Kahoot media on economic learning achievement}

The hypothesis testing of the effect of using Kahoot media on learning achievement was carried out with the help of SPSS, the following results were obtained.

Table 4. Hypothesis testing results using Kahoot media to learning achievement

\begin{tabular}{cccc}
\hline Variable & $\mathbf{t}_{\text {count }}$ & $\mathbf{t}_{\text {table }}$ & Sig. \\
\hline Use of Kahoot media & 8,196 & 1,99045 & 0,000 \\
\hline
\end{tabular}

The results of the above calculations in Table 4 show that the $\mathrm{t}_{\text {count }}$ is 8,196 and the significance level (sig.) is 0,000 . While $\mathrm{t}_{\text {table }}$ with $\mathrm{dk}=\mathrm{n}-2=81-2=79$ and $\alpha=0.05$ obtained 1.99045 (result of interpolation); thus $\mathrm{t}_{\text {count }}>\mathrm{t}_{\text {table }}$ or 8.196 $>1.990$ and Sig. $0.000<0.05$, then $\mathrm{H}_{0}$ is rejected and $\mathrm{H}_{1}$ is accepted, which means that Kahoot media use has a significant effect on Economics learning achievement of the tenth-grade students of social sciences at SMA Negeri 1 Sumberejo in the 2019/2020 academic year.

\section{The effect of question variations on Economics learning achievement}

The hypothesis testing of the effect of question variations on learning achievement was carried out with the help of SPSS, the following results were obtained.

Table 5. The Effect of question variations on Economics learning achievement

\begin{tabular}{cccc}
\hline Variable & $\mathbf{t}_{\text {count }}$ & $\mathbf{t}_{\text {table }}$ & Sig. \\
\hline Variations of questions & 4,005 & 1,99045 & 0,000 \\
\hline
\end{tabular}

Based on the results of the above calculations in Table 5, it shows that the $t_{\text {count }}$ is 4.005 and the significance level (sig.) is 0.000 . While $\mathrm{t}_{\text {table }}$ with $\mathrm{dk}=\mathrm{n}-2=81-2=79$ and $\alpha=0.05$ obtained 1.99045 (result of interpolation); thus $\mathrm{t}_{\text {count }}>\mathrm{t}_{\text {table }}$ or $4.005>1.990$ and Sig. $0,000<0.05$, then $\mathrm{H}_{0}$ is rejected and $\mathrm{H}_{1}$ is accepted, meaning that the variation of questions has a significant effect on the Economics learning achievement of the tenth-grade students of social sciences at SMA Negeri 1 Sumberejo in the 2019/2020 academic year.

\section{The effect of learning motivation on learning achievement in Economics}

The hypothesis testing of the learning motivation on Economics learning achievement was carried out with the help of SPSS, the following results were obtained. 
Table 6. Hypothesis testing results of learning motivation on Economics learning achievement

\begin{tabular}{cccc}
\hline Variable & $\mathbf{t}_{\text {count }}$ & $\mathbf{t}_{\text {table }}$ & Sig. \\
\hline Learning motivation & 7,366 & 1,99045 & 0,000 \\
\hline
\end{tabular}

Based on the results of the above calculations in Table 6, it shows that the $t_{\text {count }}$ is 7.366 and the significance level (sig.) is 0.020 . While $\mathrm{t}_{\text {table }}$ with $\mathrm{dk}=\mathrm{n}-2=81-2=79$ and $\alpha=0.05$ obtained 1.99045 (result of interpolation); thus, $\mathrm{t}_{\text {count }}>\mathrm{t}_{\text {table }}$ or 7.366 $>1.990$ and Sig. $0.000<0.05$, then $\mathrm{H}_{0}$ is accepted and $\mathrm{H}_{1}$ is rejected, meaning that learning motivation has a significant effect on Economics learning achievement among the tenth-grade students of social sciences at SMA Negeri 1 Sumberejo in the 2019/2020 academic year.

\section{The influence of using Kahoot media on Economics learning achievement through} learning motivation

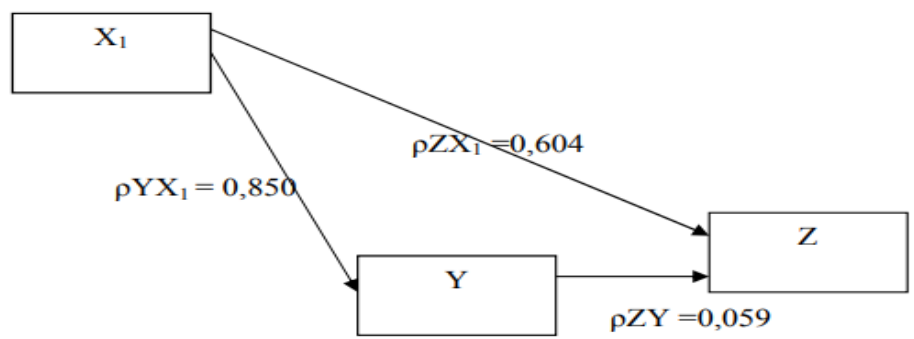

Figure 1. Indirect effect of $\mathrm{X}_{1}$ on $\mathrm{Z}$ through $\mathrm{Y}$

The path diagram in Figure 1 above shows the influence of the variable of use of Kahoot media on Economics learning achievement through learning motivation is: $\mathrm{X} 1 \mathrm{YZ}=(0.850 \mathrm{X} 0.059)$ $=0.0501(=5.01 \%)$. The value of the effect of using Kahoot media on learning achievement is indirectly obtained at 0.0501 which is positive, which means that the hypothesis reads "There is an effect of using Kahoot media on Economics learning achievement through learning motivation among the tenth-grade students of social sciences at SMA Negeri 1 Sumberejo in the 2019/2020 Academic Year" with an influence level of 5.01\%.

The influence of question variations on Economics learning achievement through learning motivation

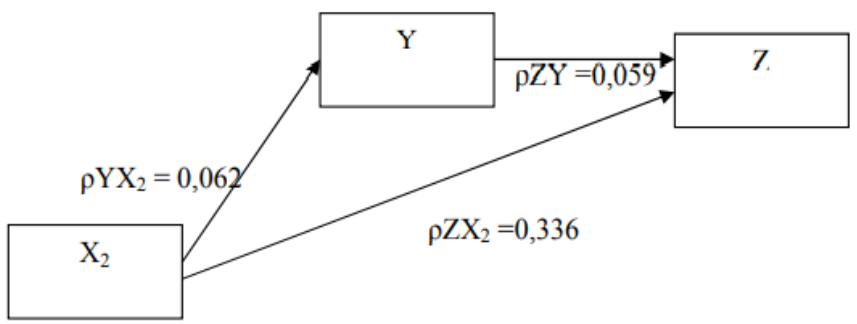

Figure 2. Indirect effect of $X_{2}$ on $\mathrm{Z}$ through $\mathrm{Y}$ 
The path diagram in Figure 2 above shows that the effect of the variation of questions on Economics learning achievement through learning motivation is: $\mathrm{X} 2 \mathrm{YZ}=(0.062 \mathrm{X} 0.059)=0.0365$ (= 3.65\%). The value of the effect of question variations on Economics learning achievement is indirectly obtained by 0.0365 which is positive. It means that the hypothesis reads "There is an effect of question variation on Economics learning achievement through learning motivation among the tenth-grade students of social sciences at SMA Negeri 1 Sumberejo for the 2019/2020 Academic Year" with an influence level of 3.65\%.

\section{The influence of using Kahoot media and variations of questions on collective learning motivation}

Hypothesis testing of using Kahoot media and variations of questions together on learning motivation was carried out with the help of SPSS. The following results were obtained.

Table 7. Hypothesis testing results using Kahoot media and variations of questions together on learning motivation

\begin{tabular}{cccc}
\hline Variable & $\mathbf{F}_{\text {count }}$ & $\mathbf{F}_{\text {table }}$ & Sig. \\
\hline $\begin{array}{c}\text { Use of Kahoot media } \\
\text { Variation of questions } \\
\text { Learning motivation }\end{array}$ & 187,981 & 3,11 & 0,000 \\
\hline
\end{tabular}

To test the hypothesis simultaneously (multiple), the F statistics was used. from the results of the above calculations using SPSS in Table 7 , it was obtained that $F_{\text {count }}=187,981$ and a significance level of $0,000 . \mathrm{F}_{\text {table }}$ with $\mathrm{dk}$ numerator $=2$ and dk denominator $=78$ with $\alpha=0.05$ or $\mathrm{F}_{\text {table }}=\mathrm{F}(0.05)$ $(2 ; 78)=3.11$ (result of interpolation). Thus $\mathrm{F}_{\text {count }}>\mathrm{F}_{\text {table }}$ or $187,981>3.11$ and a significance of 0,000 $<0.05$, then $\mathrm{H}_{0}$ is rejected and $\mathrm{H}_{1}$ is accepted. This indicates that the use of Kahoot media and question variations simultaneously and significantly affects the earning otivation of the tenth-grade students of social sciences at SMA Negeri 1 Sumberejo in the 2019/2020 academic year.

\section{The influence of using Kahoot media, question variations and collective learning motivation on Economics learning achievement}

The effect of simultaneous use of Kahoot media, question variations, and learning motivation on learning achievement was carried out with the help of SPSS. The following results were obtained.

Table 8. Hypothesis testing results using Kahoot media, variations of questions, and variations of questions together on learning motivation

\begin{tabular}{cccc}
\hline Variable & $\mathbf{F}_{\text {count }}$ & $\mathrm{F}_{\text {table }}$ & Sig. \\
\hline $\begin{array}{c}\text { Use of Kahoot media } \\
\text { Variation of questions } \\
\text { Learning motivation } \\
\text { Learning achievement }\end{array}$ & 852,855 & & \\
\hline
\end{tabular}

To test the hypothesis simultaneously (multiple), the F statistics was used. From the results of the calculation it was obtained that $\mathrm{F}_{\text {count }}=852,855$ and a significance level of $0,000 . \mathrm{F}_{\text {table }}$ with dk numerator $=3$ and $\mathrm{dk}$ denominator $=77$ with $\alpha=0.05$ or $\mathrm{F}_{\text {table }}=\mathrm{F}(0.05)(3 ; 77)=2.72$ (result of interpolation). Thus $\mathrm{F}_{\text {count }}>$ Ftable or 852.855> 2.72 and a significance of $0.000<0.05$ then $\mathrm{H}_{0}$ is rejected and $\mathrm{H}_{1}$ is accepted. This indicates that simultaneously the uses of Kahoot media, question variation, and learning motivation significantly influence the Economics learning achievement of the tenth-grade students of social sciences at SMA Negeri 1 Sumberejo in the 2019/2020 academic year. 


\section{Discussion}

The results of the calculations show that $t_{\text {count }}>t_{\text {table }}$ or $4.786>1.990$ and Sig. $0.000<0.05$, then $\mathrm{H}_{0}$ is rejected and $\mathrm{H}_{1}$ is accepted, which means that Kahoot media use has a significant effect on learning motivation for the tenth-grade students of social sciences at SMA Negeri 1 Sumberejo in the 2019/2020 academic year. Based on the results of calculations with SPSS, the path coefficient of $\rho Y X 1$ was found to be 0.850 , meaning that the influence of Kahoot media on learning motivation was 0.850 or $85 \%$, the remaining $15 \%$ was influenced by other factors not examined in the study. This study's results are in line with Caroly and Julia's finding (as cited in Izzati \& Kuswanto, 2019) research that Kahoot is an online quiz that involves students' active thinking with learning content that emphasizes attention and learning objectives (Putri, Romadilah, \& Wiganingrum, 2018). Kahoot can make it easier for teachers to evaluate. It is undeniable that technology can be an attractive learning medium, and utilizing learning applications can make it easier for teachers to manage and convey messages to students who are more motivated and independent (Rofiyarti \& Sari, 2017).

Hypothesis testing of the effect of question variations on learning motivation was carried out with the help of SPSS. The results of the calculations show that $t_{\text {count }}>t_{\text {table }}$ or $4.043>1.990$ and Sig. $0.000<0.05$, then $\mathrm{H}_{0}$ is rejected and $\mathrm{H}_{1}$ is accepted, which means that the use of question variations has a significant effect on learning motivation for the tenth-grade students of social sciences at SMA Negeri 1 Sumberejo in the 2019/2020 academic year. Based on the results of calculations with SPSS, the path coefficient $\rho$ YX2 was obtained, which was 0.062 , meaning that the influence of the variation of questions on learning motivation was 0.062 or $6.2 \%$, the remaining $93.8 \%$ was influenced by other factors not examined in the study. This study's results are in line with research conducted by Amanatusifah (2013), which shows that the results of the study have a significant effect between the formative test and the learning motivation of students of SMPN 2 Batang Peranap Middle School, Batang Peranap District, Hulu Regency. Thus $r_{\text {count }}>r_{\text {table }}$ at a significance level of $1 \%$ or $5 \%$ or in other ways it can be written as $0.325<0.681>0.418$. The results of the study are in line with Pophams's (1999) statement that the affective domain determines the learning success of a person, people who do not have interest, positive attitudes, and learning motivation in certain subjects will find it difficult to be able to achieve optimal learning success.

The correlation figure between the use of Kahoot and question variations is 0.964 . This means that the relationship between the variable use of Kahoot media and variation of questions is strong and unidirectional (because the results are positive). It is said in the same direction, meaning that if Kahoot media use is maximal, the variation of questions will be maximized. The correlation between the two variables is significant because the significance value is $<0.05$, or sig. (2-tailed) $0.000<0.05$. The results of this study are in line with research conducted by Izzati \& Kuswanto (2019) showing that the Paired Sample T-Test that the Kahoot-assisted blended learning model has a significant effect on student learning motivation with $t_{\text {count }}>t_{\text {table }}$. The research results above are in line with (Effendi, 2017), that states that Bloom's Taxonomy is used as a benchmark in assessment, where the structure classifies the level of thinking from a low level to a high level. In line with this, Thomas (2014 as cited in Dellos, 2015), states that the speed and ease of access to Kahoot benefit students and teachers in reviewing new and old lessons. Kahoot can be used for various assessments and assignments, including formative assessments, diagnostics, research projects, and presentations. Based on the explanation above, the use of Kahoot media is related to a variety of questions. The Kahoot media has a quiz game in writing, pictures, or videos.

Looking at the effect of Kahoot on learning environment, the path coefficient $\rho \mathrm{ZX} 1$ is obtained at 0.604, which means that the magnitude of the influence of the use of Kahoot media on Economics learning achievement is X1 Z $=\rho Z X 1 \times \rho Z X 1=(0.604 \times 0.604)=03648(=36.48 \%)$ the remaining $63.52 \%$ are influenced by other factors not examined in this study. The results of this study are in line with the research done by Mafruhah, Sulistiani, \& Mustafida (2019) that the use of interactive learning media based on the Kahoot application affects the Economics learning outcomes high school student, meaning that the use of application-based learning media is effective. This research is in line with the opinion of Sole \& Anggraeni (2018) that teachers and students are required to use technology. This means that a teacher and students have the ability to master Kahoot media to support learning achievement in the teaching and learning process. Based 
on such understanding, Kahoot educative online games-based learning improves student achievement with a way to review the subjects that they have studied or are not studied.

Regarding the effect of question variations on learning achievement, the path coefficient $\rho Z X 2$ is obtained at 0.336 , which means that the influence of the variation of questions on Economics learning achievement is $\mathrm{X} 2 \mathrm{Z}=\rho \mathrm{ZX} 2 \times \rho \mathrm{ZX} 2=(0.336 \times 0.336)=0.1129(=11.29 \%)$ the remaining $88.71 \%$ influenced by other factors not examined in this study. The results of this study are in line with Popham's (1999) opinion that the affective domain determines the learning success of a person. People who do not have interest, positive attitudes, and learning motivation in certain subjects find it difficult to be able to achieve optimal learning success. In line with this study, Tu'u (2004) states that learning achievement is the mastery of knowledge or skills developed by subjects, usually indicated by test scores or numbers given by the teacher. Based on the above understanding, it can be concluded that Economics learning achievement is the result achieved by students in Economics learning activities which are indicated by the values or figures of the evaluation results after the learning process.

Learning motivation also has a significant effect on Economics learning achievement. The path coefficient of $\rho Z Y$ is 0.059 , which means the magnitude of the influence of learning motivation on Economics learning achievement is $\mathrm{YZ}=\rho \mathrm{ZY} \times \rho \mathrm{ZY}=(0.059 \times 0.059)=0.0348(=3.48 \%)$ the rest, $96.52 \%$, are influenced by other factors not examined in this study. This is in line with what was found by Iswahyuni (2016) social studies learning motivation of junior high school students falls into high, high enough, and medium categories. This resonates with Sardiman's (2000) finding that in learning activities, motivation can be said to be the overall driving force within students that creates, ensures continuity, and provides direction for learning activities so that it is expected that goals can be achieved. According to Uno (2008), the essence of learning motivation is the internal and external encouragement of students who are learning to make behavioral changes, generally with several indicators or supporting elements. Therefore, it can be said that learning motivation is encouragement that comes from within and outside a person so that it can foster a sense of enthusiasm for student learning to achieve student learning achievement.

The hypothesis testing to look at the influence of Kahoot media on eEconomics learning achievement through learning motivation was carried out through a path diagram. Based on the path diagram, it can be calculated the influence of the variable use of Kahoot media on Economics learning achievement through learning motivation is $\mathrm{X} 1 \mathrm{YZ}=(0.850 \mathrm{X} 0.059)=0.0501(=5.01 \%)$. The value of the effect is indirectly obtained at 0.0501 which is positive, which means that the hypothesis reads "There is an effect of using Kahoot media on Economics learning achievement through learning motivation among the tenth-grade students of social sciences at SMA Negeri 1 Sumberejo in the 2019/2020 Academic Year" is accepted with an influence level of 5.01\%. It is in line with research conducted by Mafruhah et al. (2019), showing that the use of interactive learning media which was based on application (Kahoot) affects the learning outcomes of high school students.

This is in line with Rofiyarti \& Sari (2017) that Kahoot application can make it easier for teachers to evaluate. It is undeniable that technology can be an attractive learning media and utilizing learning applications it can make it easier for teachers to manage and deliver messages to students. According to Thomas (2014 as cited in Dellos, 2015) that the speed and ease of access to Kahoot benefit students and teachers in reviewing new and old lessons. Kahoot can be used for a wide variety of assessments and assignments, including formative assessments, diagnostics, research projects, and presentations. Motivation and learning are two things that influence each other. Learning is a relatively permanent change in behavior and can potentially occur as a result of practice or reinforced practice based on goals to achieve certain goals. Based on the explanation above, it can be concluded that Kahoot is a learning media based on online educative games to adjust teaching to the level of student knowledge where students try to find the correct answers to questions prepared in advance by the teacher, which are displayed on the projector screen and can also be used on any device connected to the Internet (computers, notebooks, tablets, cellphones, etc.), get motivated with rewards, earn points they win and find opportunities to gain control of information skills they learn in class and become leaders in group competitions as well. 
Regarding the influence of question variations on Economics learning achievement through learning motivation, the value of the effect of question variations on Economics learning achievement is indirectly obtained at 0.0365 which is positive. It means that the hypothesis reads "There is an effect of question variation on Economics learning achievement through learning motivation for the tenth-grade students of social sciences at SMA Negeri 1 Sumberejo for the 2019/2020 Academic Year" is accepted with an influence level of 3.65\%. This resonates with what was stated by Bafadal (2004) that educational infrastructure is all basic equipment that indirectly supports the implementation of the educational process in schools. According to Popham (1999), the affective domain determines the learning success of a person. People who do not have an interest, positive attitudes, and motivation to learn in certain subjects find it difficult to achieve optimal learning success.

Turning to the simultaneous use of Kahoot and variations of questions on learning motivation, the F statistics was used to test the hypothesis. It was found that the simultaneous use of Kahoot media and question variations significantly affects students' learning motivation. The student learning motivation variable is influenced by the variable use of Kahoot media and question variations of $82.8 \%$, and the remaining $17.2 \%$ is influenced by other factors not examined in this study. The explanation above agrees with Gaudelli (2014), who states that diversity and creativity are needed in the teaching and learning process so that the learning atmosphere is more pleasant, comfortable so that lessons can be understood more easily. Agreeing with Gaudelli, (Dellos, 2015) states that the quiz in Kahoot application is not only in the form of written questions but can be inserted with pictures, videos, and songs to support students' thinking power in understanding the quiz.

It was also found that the simultaneous use of Kahoot media, question variation, and learning motivation significantly influences students' Economics learning achievement with a level of determination of 0.971 or $97.1 \%$, which means that the student learning motivation variable is influenced by the use of Kahoot variable and the variation of questions by $97.1 \%$, the remaining $2.9 \%$ is influenced by other factors not examined in this study. The results of this study agree with Sardiman (2000) finding that learning activities, motivation can be said to be the overall driving force within students that creates, ensures continuity, and provides direction for learning activities so that it is expected that goals can be achieved. Internal factors experienced and lived by students affect the learning process, according to Dimyati (2006), one of which is motivation. McClelland (as cited in Majid, 2013) stated that motivation varies according to the strength of a person's need for achievement. Murray (1977 as cited in Winardi, 2000) defines the need for achievement as the desire to carry out a difficult task or job, to control, manipulate, or organize physical objects, humans, or ideas to carry out these things as quickly as possible.

In connection with this, external factors that influence the learning process in this study are the use of Kahoot media and variations of questions. Rofiyarti \& Sari (2017) suggest that Kahoot application can make it easier for teachers to evaluate. It is undeniable that technology can be an attractive learning media, and utilizing learning applications can make it easier for teachers to manage and convey messages to students. The second factor that affects learning achievement is the variety of questions. According to Popham (1999), the affective domain determines the learning success of a person. People who do not have an interest, positive attitudes, and motivation to learn in certain subjects find it difficult to achieve optimal learning success.

Therefore, it can be stated that the optimal use of Kahoot media can encourage student learning motivation. Likewise, a complete variety of questions will give students enthusiasm for learning. Thus, learning motivation arising from Kahoot media and a complete variety of questions will support student learning achievement.

\section{Conclusion}

Based on the results and discussion above, the following conclusions can be drawn.

1. There is an effect of Kahoot media use on learning motivation of the tenth-grade students of social sciences at SMA Negeri 1 Sumberejo in the 2019/2020 academic year. The use of Kahoot 
media plays a very important role in increasing student motivation. If Kahoot is optimally used, students' learning motivation will increase, and vice versa.

2. There is an effect of question variations on the tenth-grade students' learning motivation at SMA Negeri 1 Sumberejo in the 2019/2020 academic year. If the variety of questions in school is complete, students' learning motivation will increase, and vice versa.

3. There is a relationship between Kahoot media use and the variation of questions for the tenthgrade students of social sciences at SMA Negeri 1 Sumberejo in the 2019/2020 academic year. Kahoot is one of the learning facilities at school. If it is well used, the variety of questions will increase, and vice versa.

4. There is a direct effect that motivates use on the Economics learning achievement of the tenthgrade students of social sciences at SMA Negeri 1 Sumberejo in the 2019/2020 academic year. Learning using Kahoot media will enhance an effective learning process. If the use of Kahoot media is increased, learning achievement will increase, and vice versa.

5. There is a direct effect of question variations on the tenth-grade students' Economics learning achievement at SMA Negeri 1 Sumberejo in the 2019/2020 academic year. A complete variety of questions will support student achievement. If the variety of questions is great, then the Economics learning achievement will increase, and vice versa.

6. There is an effect of learning motivation on the tenth-grade students' Economics learning achievement at SMA Negeri 1 Sumberejo in the 2019/2020 academic year. Motivation is needed in the learning process. If the student's learning motivation is high, then their Economics learning achievement will increase, and vice versa.

7. There is an effect of Kahoot use on Economics learning achievement through learning motivation among the tenth-grade students of social sciences at SMA Negeri 1 Sumberejo in the 2019/2020 academic year. Kahoot will create a more effective learning process. If the use of Kahoot is high, then student learning motivation will increase, affecting the increase in Economics learning achievement and vice versa.

8. There is an effect of question variations on Economics learning achievement through students' learning motivation at SMA Negeri 1 Sumberejo in the 2019/2020 academic year. Variation of questions is to support learning achievement. If the variety of questions is great, then the student's learning motivation will increase, affecting the increase in Economics learning achievement and vice versa.

9. There is an effect of e simultaneous use of th Kahoot and variations of questions among the tenth-grade students of social sciences at SMA Negeri 1 Sumberejo in the 2019/2020 academic year. Kahoot is a component of learning facilities. If the use of Kahoot and question variations are high, then students' motivation will increase and vice versa.

10. There is an effect of the simultaneous use of Kahoot, variations of questions, and learning motivation on Economics learning achievement among the tenth-grade students of social sciences at SMA Negeri 1 Sumberejo in the 2019/2020 academic year. Kahoot and a variety of complete questions will increase student motivation. If use of Kahoot and variety of questions are high, learning motivation will increase. It will increase students' Economics learning achievement, and vice versa.

\section{Acknowledgements}

The authors express gratitude to the school principal, teachers, and tenth-grade students of social sciences at SMA Negeri 1 Sumberejo, Lampung Province, Indonesia for their help and participation in this study. Our gratitude also goes to the anonymous reviewers for providing us with constructive feedback on the earlier version of this paper.

\section{Funding}

This research received no specific grant from any funding agency in the public, commercial, or not-for-profit sectors. 


\section{References}

Amanatusifah, S. (2013). Pengaruh tes formatif terhadap motivasi belajar siswa dalam mata pelajaran pendidikan agama Islam (Studi kasus di sekolah menengah pertama negeri 2 Batang Peranap Kecamatan Batang Peranap Kabupaten Indragiri Hulu). Universitas Islam Negeri Sultan Syarif Kasim Riau

Azhar, A. (2007). Media pembelajaran, Jakarta: PT. 15-85.

Bafadal, I. (2004). Manajemen perlengkapan sekolah teori dan aplikasinya.

Bennett, W. L. (2007). Civic life online: Learning how digital media can engage youth: The MIT Press.

Boden, G. M., \& Hart, L. (2018). Kahoot-Game Based Student Response System. 11(1).

Dellos, R. (2015). Kahoot! A digital game resource for learning. 12(4), 49-52.

Dewi, C. K. (2018). Pengembangan alat evaluasi menggunakan Aplikasi Kahoot pada pembelajaran Matematika Kelas $X$. UIN Raden Intan Lampung,

Dimyati, M. (2006). Belajar dan pembelajaran.

Effendi, R. (2017). Konsep revisi taksonomi Bloom dan implementasinya pada pelajaran matematika SMP. 2(1).

Gaudelli, W. (2014). World class: Teaching and learning in global times: Routledge.

Idris, F., Hassan, Z., Ya'acob, A., Gill, S. K., \& Awal, N. A. M. (2012). The role of education in shaping youth's national identity. 59, 443-450.

Iswahyuni, i. (2016). Pengaruh motivasi belajar terhadap prestasi belajar ips siswa smp negeri 4 sungguminasa kabupaten Gowa. fakultas Ilmu Sosial,

Izzati, M., \& Kuswanto, H. (2019). Pengaruh model pembelajaran blanded learning berbantuan kahoot terhadap motivasi dan kemandirian siswa. 3(2), 68-75.

Krathwohl, D. (2002). A revision of Bloom's taxonomy in theory into practice. In: Ohaio State University.

Mafruhah, S., Sulistiani, I. R., \& Mustafida, F. (2019). Pengaruh Penggunaan Media Pembelajaran Interaktif Berbasis Aplikasi (Kahoot) Terhadap Hasil Belajar Siswa Kelas XI di SMAI Al-Maarif Singosari Malang. 4(7), 23-29.

Majid, A. (2013). Strategi pembelajaran. In: Bandung: PT Remaja Rosdakarya.

Popham, W. J. (1999). Classroom assessment: What teachers need to know. ERIC.

Putri, A. N., Romadilah, F., \& Wiganingrum, T. (2018). Desain tes berbasis kontekstual dengan permainan kahoot pada pembelajaran fisika materi momentum dan impuls.

Rofiyarti, F., \& Sari, A. Y. (2017). TIK untuk AUD: Penggunaan platform "Kahoot!" dalam menumbuhkan jiwa kompetitif dan kolaboratif anak. 3(3b).

Sardiman, A. M. (2000). Interaksi \& motivasi belajar mengajar: PT RajaGrafindo Persada.

Setiawati, H. D., Sihkabuden, S., \& Adi, E. P. (2019). Pengaruh Kahoot! Terhadap Hasil Belajar Siswa Kelas XI di SMAN 1 Blitar. 1(4), 273-278.

Sole, F. B., \& Anggraeni, D. M. (2018). Inovasi pembelajaran elektronik dan tantangan guru abad 21. 2(1), $10-18$.

Susanto, A. (2013). Teori belajar dan pembelajaran di sekolah dasar. In: Jakarta: Kencana prenada media group.

Tu'u, T. (2004). Peran disiplin pada perilaku dan prestasi siswa. 82.

Uno, H. B. (2008). Teori motivasi \& pengukurannya.

Winardi, J. (2000). Kepemimpinan dalam manajemen.

Youssef, A. B., \& Dahmani, M. (2008). The impact of ICT on student performance in higher education: Direct effects, indirect effects and organisational change. 5(1), 45-56. 